\title{
MADONAS PILSĒTAS INŽENIERIS VOLDEMĀRS BERGKINDS (1897-1978)
}

\author{
INDULIS ZVIRGZDIN̦Š*, \\ Madonas Novadpētniecības un mākslas muzejs
}

Kopsavilkums. Būvinženieris Voldemārs Bergkinds sāka studijas Rīgas Politehniskajā institūtā, beidza Latvijas Universitāti 1922. gadā. Viṇš bija ceḷu inženieris Satiksmes ministrijā, bet arī projektēja dažādas jaunceltnes un ēku pārbūves. Vairākas viṇa plānotas celtnes saglabājušās Madonā, kur kopš 1928. gada V. Bergkinds bija pilsētas inženieris. Pēc Otrā pasaules kara viṇš dzīvoja Austrijā, piedalījās Raiṇa un Aspazijas pieminekḷa iekārtošanā Šveicē, Kastaņolā.

Atslēgvārdi: Voldemārs Bergkinds, ceḷu būve, ēku projektēšana, Madona, Raiṇa un Aspazijas pieminna Šveicē.

\section{Izglītības un darba gaitu sākums}

Voldemārs Johans Bergkinds, parasti saukts par Voldemāru Bergkindu, dzimis 1897. gada 7. septembrī koku brāksera Indriķa Bergkinda un viṇa sievas Annas Krūzes-Bergkindas gimenē Sarkandaugavā, Mangaḷu pagastā [1]. 1915. gadā vin,š beidza Rīgas pilsētas reālskolu, vēl gadu mācījās Petrogradas 2. reālskolas papildklasē, tad 1916. gadā iestājās uz Maskavu evakuētā Rīgas Politehniskā institūta Inženieru nodaḷā. 1919. gada 16. septembrī viņš rakstīja lūgumu Latvijas Augstskolas rektoram par uzn,emšanu Inženieru fakultātē, norādot, ka divus kursus beidzis RPI [2]. Taču jau 5. oktobrī sekoja brīvprātīga iestāšanās karadienestā, nākamajā pavasarī vinsš to kapteiṇa dienesta pakāpē atstāja. 1922. gada 23. decembrī LU Sevišķā pārbaudīšanas komisija V. Bergkindam kā beigušam pilnu kursu pēc bijušā Rīgas Politehniskā institūta

\footnotetext{
* Korespondējošais autors.

E-pasts: i.zvirgzdins@madona.lv
} 


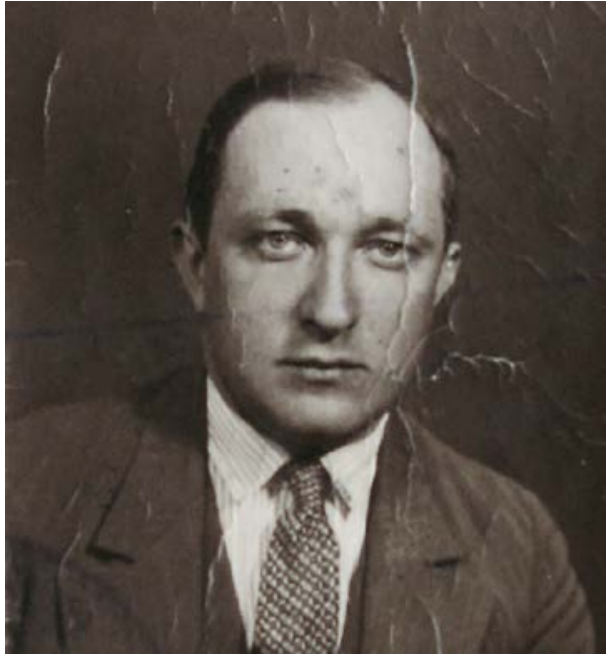

1. attēls. Voldemārs Bergkinds 20. gadsimta 20. gados [5].

inženierzinātṇu programmas piešķīra būvinženiera grādu, ko Universitātes padome apstiprināja 1923. gada 10. janvārī [3]. Ir norādes, ka viṇš ir beidzis «Konservatorijas klavieru klasi» [4], domājams, Latvijas Konservatorijā vai Latvijas Tautas konservatorijā, taču šādas ziṇas arhīvu dokumentos nav atrodamas. Studiju laikā jauneklis apprecējās ar vēlāko operdziedātāju Zelmu Gothardi (1897-1964), 1920. gadu otrā pusē laulība šķirta. Jāpiebilst, ka ar mūziku cieši saistīta bija ne tikai pirmā dzīvesbiedre. 1933. gadā viṇš apprecējās otrreiz - ar dziedātāju Almu Langholci, pēc laulībām Almu Langholci-Bergkindi [5].

Ziṇas par turpmāko inženiera dzīvi vairāk gūtas no Latvijas preses, jo Satiksmes ministrijas dienestā strādājušo materiāli arhīvā saglabāti nepilnīgi. Iekšlietu ministrijas būvvalde 1923. gada vasarā LU beidzējam apstiprināja būvinženiera tiesības [6], kā tā adrese tobrīd norādīta Kalnciema 1. līnija 22 Vecmīlgrāvī, vēlāk V. Bergkinds dzīvoja Altonavas ielā 13b. Sākumā viṇš strādāja Rīgas pilsētas būvvaldē, tad gadu bija Zemkopības ministrijas Lauksaimniecības departamenta brīva līguma 1. šķiras inženieris [7], pēc tam strādāja Satiksmes ministrijas Šoseju un zemescel̦u departamentā, bet ārpus pamatpienākumiem ik pa laikam piedalījās arī kādu jaunu ēku celtniecības vai esošu pārbūves plānošanā: Galgauskas dziedāšanas biedrības nams, skolas ēkas Bēnē, Rauzā un Skrīveros 20. gados, slimnīca Jaunjelgavā un skolas jaunceltne Omuḷos, skolas pārbūve Ezerē un Nīgrandē nākamajā desmitgadē. Ēkas ir tās, kas arī šodien mums atgādina viṇa kādreizējo veikumu, jo pirms gadu desmitiem veidotie cel̦i izmainījušies vairāk. 


\section{Veikums Madonā}

1927. gada augustā Satiksmes ministrs apstiprināja V. Bergkindu par Valkas-Madonas apriņķu cel̦u inženieri [8]. Pieminēts, ka vinšs piedalījies Rīgas-Tallinas šosejas projektēšanā Latvijas teritorijā un ceḷu un dambju plānošanā Keguma spēkstacijas rajonā, vecais ceḷš savulaik gāja gar Daugavas krastu, sakarā ar būvdarbiem to vajadzēja attālināt no upes, iztaisnot [4]. Savukārt daḷa no iepriekš nosauktajām ēkām atradās Valkas aprin,kīi.

Bez pamatdarba Satiksmes ministrijā no 1928. gada 1. aprīḷa inženieris Bergkinds sāka pildīt Madonas pilsētas inženiera pienākumus [9]. Pirms viṇa šai amatā bija RPI absolvents Gustavs Zosulis (1878-1933). Voldemāram Bergkindam tas bija papilddarbs ar pamatalgu 120 latu mēnesī, pilsētā vinš ieradās tikai atsevišḳās reizēs, dome ar inženieri daudz sazinājās rakstiski. Viens no darbietilpīgākajiem viṇa pienākumiem bija caurskatīt un novērtēt projektus, kas tika iesniegti pilsētas būvkomisijā. Tajā darbojās atsevišķ domes deputāti, kam varēja būt kāda praktiska celtniecības pieredze, taču noteikti pietrūka inženiera izglītības. Būvkomisijas ațlauju vajadzēja visiem privāto un sabiedrisko ēku celtniecības, pārbūves darbiem pilsētā. Sabiedriskas nozīmes celtṇu būvprojektus izskatīja arī Iekšlietu ministrijas Būvniecības pārvaldē Rīgā. Privāto ēku atbilstību drošībai un citām prasībām pamatā vērtēja pilsētas inženieris. Šo darbu veica V. Bergkinds. Vienlaikus vinš̌ arī gatavojis atsevišku celtṇu projektus pilsētā un apkārtnē.

Pēc V. Bergkinda projektiem Madonā celta ebreju sinagoga Dārza ielā (nodedzināta 1941. gadā pēc vācu armijas ienākšanas) un Romas katoḷu baznīca Liepājas ielā (pirmo plānu koka būvei pēc priestera M. Dukaḷska aicinājuma 1928. gadā zīmēja arhitekts B. Leilands, V. Bergkinda 1931. gada martā gatavotais plāns paredzēja ārējās formās līdzīgu k̦iegeḷu celtni, ko pabeidza nākamajā pavasarī [10]), pilsētas morgs iepretī kapsētai Blaumaṇa ielā (nojaukts 90. gados), tirdzniecības būdas Tirgus laukumā (nojauktas 60. gadu vidū sakarā ar rajona administratīvās ēkas celtniecību). Apriṇķī būvinženieris izstrādāja pārbūvju projektus Dzelzavas aizsargu namam bijušajā muižas klētī, Gulbenes slimnīcai, Kalsnavas pagastnamam, Saikavas Kalna skolai un Sāvienas tautas namam agrākajā muižas kungu namā.

1933. gadā projektētajā nelielajā Jāṇa Šustera privātmājā Madonā, Baloža ielā, var saskatīt etnogrāfiskās celtniecības ietekmes [11]. Gadu vēlāk V. Bergkinds plānoja ǵimenes māju Tirgus laukumā 7 Madonas kara apriṇk,a pārvaldes virsniekam Pēterim Plātem (1895-1950) un viṇa dzīvesbiedrei Olgai [12]. Uzcelta divstāvu apmesta koka stāvbūve ar astoñām istabām, kopplatība 148 m², būvniecība izmaksājusi 23000 latu. Tajā atpazīstamas funkcionālisma formas. 1939. gadā Hipotēku bankas 
izvirzīta komisija, kurā darbojās arhitekts Pauls Kundziņš (18881983), būvinženieri Teodors Rušiņš (1899-1967) un Valentīns Zariņš (1901-1968), citi bankas pārstāvji, salīdzināja pēdējās piecgades (kopš 1934. gada 15. maija) Latvijā uzceltās gimenes mājas. Skatītas tā sauktās mazēkas, kas iecerētas vienas - divu gimennu izmantošanai. Izvēlētas ne dārgākās un greznākās, bet tādas, kas celtas piemēroti vietai un apstākliem, izmantojot vietējos materiālus. Vērtēts labiekārtojums, atbilstība arhitektoniskajām un būvtehniskajām prasībām [13]. Kopā pieškīira trīs pirmās, trīs otrās un trīs trešās godalgas. Starp 450 latu otrās godalgas ieguvējiem bija arī madonieši Plātes, tas reizē ir arī inženiera V. Bergkinda projekta novērtējums.

Tomēr būtiskākā jaunceltne Madonā, ko projektējis Voldemārs Bergkinds, bija pilsētas pamatskola (2. attēls). Senākā ēka ar skolas funkcijām pilsētas teritorijā bija kādreizējais pagastnams vēlākajā Parka ielā, bērni no 1870. gada rudens līdz 1893. gadam mācījās tā jumta stāvā. Vēlāk skola atradās Sarkaṇos, jo Madonas muižas teritorija tad iekḷāvās Sarkaṇu pagastā. Pēc Latvijas Republikas nodibināšanas pamatskolas vajadzībām īrētas telpas privātmājās, sākumā Rīgas ielā 1, no 1926. gada beigām - Rīgas ielā 4, kur iepriekš darbojās vidusskola. Tā tika pārvietota uz arhitekta Arnolda Maidela (1884-1946) projektēto jaunceltni Skolas ielā 10. Kopš 1921. gada pastāvēja Madonas miests, 1926. gada vasarā Madonai pieškirtas pilsētas tiesības. Pašvaldībā tika spriests par pamatskolas jaunbūves nepieciešamību. Trīsstāvu ēkas projektu 1926. gada pavasarī piedāvāja būvtehniķis Eduards Smurğis [14]. 30. gadu sākumā savu trīsstāvu U-veida skolas ēkas projektu [15] sagatavoja inženieris Alberts Neiders (1893-1942), kas tolaik vadijja Satiksmes ministrijas Šoseju un zemescel̦u departamenta 10. rajonu Madonā. Taču abi šie projekti tika atzīti par pārāk dārgiem. Vienu brīdi bija iecere pamatskolas vajadzībām pārbūvēt kādreizējo muižas ūdensdzirnavu èku (projektēšanā iesaistījās V. Bergkinds), taču dzīvē to pārkārtoja slimnīcas vajadzībām. 1932. gadā pilsētas dome skolas jaunceltnes projektu pasūtīja inženierim V. Bergkindam. Jādomā, par šo veikumu viṇš sañēma papildsamaksu virs noteiktās mēnešalgas. 1933. gada pavasarī sagatavots celtnes plāns [16]. Ar inženiera parakstu sagatavoti arī galvenie izpildāmo būvdarbu aprēķini. Jānis Krastinš̌ to pieskaita ēkām, «..kuras arhitektūrā funkcionālisma formālie paṇēmieni lietoti vairāk vai mazāk uzskatāmi» [17]. Būvlaukums atradās kādreizējās Madonas muižas rijas vietā Skolas ielā iepretī Upes ielai. Plānotā L-veida divarpus stāvu ēka cel̦ama divās kārtās. Tika īstenota pirmā daḷa, 1940. vai 1941. gadā plānoto otrās kārtas celtniecību izjauca Otrais pasaules karš. Šajā dienvidrietumu puses piebūvē būtu zāle, garderobe, vēl trīs klašu telpas un pārziņa trīsistabu dzīvoklis ar atsevišķu ieeju. Celtniecību sāka 1933. gada 17. jūnijā, skolas namu iesvētīja 1934. gada 1. decembrī. 
Būvdarbiem izlietots 78118 latu [18]. Inženiera aprēḳini sākotnēji paredzēja 92,5 tūkstošus latu lielu izmaksu. Projekta autors reizē pildīja arī būvuzrauga pienākumus. Celtniecību izdeva mazāksolīšanā būvuzṇēmējam, kas apṇēmās to veikt lētāk. Inženieris sagatavoja arī darbu izsoles noteikumus. Pirmo pusbūvi (ēkas stāva uzcelšanu) veica Rīgas būvuzṇēmējs Jānis Mālītis, iekšējos apdares darbus pēc tam organizēja madonietis Pēteris Rozītis. Pilsētas domei sūtītās vēstules rāda, ka V. Bergkinds sekojis līdz celtniecības darbiem.

«Madonas pilsētas valdei. Pamatojoties uz uzṇēmēja Mālītis kga pievestiem datiem, ka pamatu mūrēšanas darbi tikko iesākti, savu izbraukumu uz Madonu noliku 3. vai 4. jūlijā. Ja darbu gaita to steidzoši prasītu, varu izbraukt 2. jūlijā, t. i., svētdien, bet domāju, ka darbā traucējumus tas neradīs, ja iebraukšu 3. vai 4./VIII. Nosūtu pagaidām pagraba stāva darba zīmējumu. Pārējos darba zīmējumus aizvedīšu, kad braukšu..» zīmīte domē san,emta 1933. gada 29. jūnijā [19].

«9. un arī 10. sept. Madonā ierasties nevaru. Palieku pārliecībā, ka visi darbi arī bez manis tiks veikti un spāres būs drošas un stipras. Ar svētdienas pastu nosūtīšu trepju kalkulāciju un arī norādījumus par

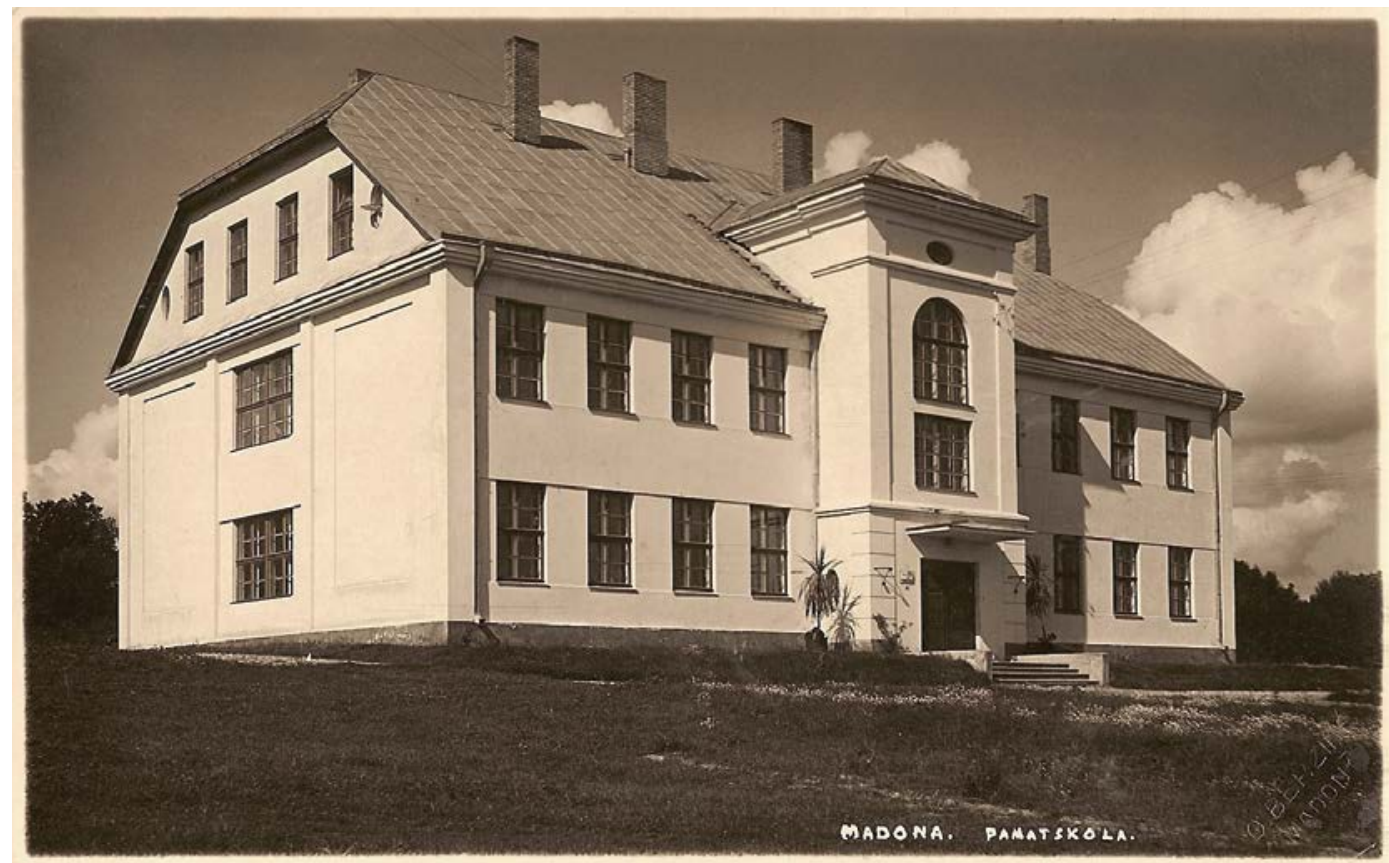

2. attēls. Madonas pilsētas pamatskola 20. gadsimta 30 gados. Foto no Madonas Novadpētniecības un mākslas muzeja fondiem. 
skārda jumtu. Madonā paredzu būt ap 16. sept. Inž. V. Bergkinds Rīgā 8./ IX.33. g.» [19].

Inženieris V. Bergkinds sagatavoja būves kopplānu, kurā gan darba gaitā tika veiktas atsevišksas izmainas. Pirmajā variantā bija paredzēta krāšnu apkure, taču celtniecības gaitā dome izškšīāàs par centrālapkuri. Tās projektēšanu pamatskolai veica cits speciālists, arī uz apkures sistēmas piennemšanu pilsētas inženieris delegéja savu kolēgi Voldemāru Sproǵi [20]. 1935. gada beigās V. Bergkinds uzzīmēja plānu nelielai saimniecības ēkai pie skolas, tajā atradās malkas šḳūnis un arī rokdarbu klase.

1942. gadā žurnālā «Satiksme un Tehnika» divos turpinājumos lasāms inženiera V. Bergkinda raksts «Ielu uzlabošana mūsu mazpilsētās». Autors salīdzina tolaik ierastākos ielu segumus - grants, laukakmenuu bruğis, apskaldìtu akmennu bruğis, šķembu klājums un bituminēts klājums (izmantojot darvu vai bitumenu), raksturo to piemērotību pajūgu un auto transportam, izmantošanas ērtumu, ūdens novadīšanas iespējas, remonta biežuma nepieciešamību, uzturēšanas izmaksas.

\section{Darbs ārzemēs}

1943. gada janvārī inženieris komandēts uz Vāciju ceḷu celtniecības darbos pie Potsdamas, tad Minhenes, neilgi strādāja arī Minhenes Tehniskajā augstskolā, vēlāk pārcēlās uz Austriju. Latvietis V. Bergkinds piedalījās Grosgloknera augstkalnu ceḷa pārbūvē dienvidos no Zalcburgas, pēc tam strādāja augstkalnu spēkstaciju projektēšanā Kaprunā, tad Insbrukas pilsētas ūdensapgādē. Insbrukā inženieris palika dzīvot arī pēc pensionēšanās 1965. gadā. Zināms, ka tolaik viņš darbojies vietējā baznīcā kā ērǵelnieks - noprotams, ka papildizglītību ērǵel̦u un klavieru spēlē rīdzinieks saṇēmis Maskavas studiju periodā [21].

\section{Raiṇa un Aspazijas piemiṇai}

Pēc pensionēšanās Austrijā dzīvojot, V. Bergkinds iesaistījās Raiṇa un Aspazijas pieminnas vietas veidošanā Šveicēe, Kastaṇolā (Lugano pilsētas daḷa). Ieceres par tādu vai citādu pieminekli tika izteiktas dzejnieka 100. dzimšanas dienas pasākumā 1965. gada septembrī, nākamajā gadā ASV nodibināta Raiṇa un Aspazijas pieminekḷa komiteja (RAPK), kam gan bija nesaprašanās ar galvenokārt Stokholmā centrēto Raiṇa un Aspazijas fondu (RAF) un arī Kastaṇolas municipalitātes pārvaldi [22]. Kārḷa Dzelzīša (1892-1982) vadītajā RAPK V. Bergkinds bija komitejas pārstāvis Austrijā, arī Šveicē. Attālums no Insbrukas līdz Lugano caur Cīrihi pārsniedza $450 \mathrm{~km}$, tomēr no komitejas aktīvistiem inženieris 
Bergkinds dzīvoja salīdzinoši tuvāk, tāpēc viṇam samērā bieži nācās doties uz dzejnieku kādreizējo mītnes vietu. Viṇš rūpējās par bronzas ciḷnu un uzrakstu plākšn,u izgatavošanu piemineklim Mendrizio pilsētiṇā dienvidos no Lugano pēc Anglijā dzīvojošā Roberta Plātes (18981991) zīmējumiem. R. Plāte savulaik arī strādājis Satiksmes ministrijā. 75. dzimšanas dienu kādreizējais rīdzinieks sagaidīja Kastaņolā, kur tika veikti pēdējie pieminekḷa sagatavošanas darbi.

Pieminekḷa atklāšanā 1972. gada 9. septembrī inženieris pastāstīja par tā veidošanu:

«..Pieminekḷa tapšana nebija viegla. Bija jāpārvar dažādas klūumes un šksēršlı.i. Bija brīži, kad likās - mēs ar šo uzdevumu - pieminekḷa uzcelšanu - galā netiksim. Bija jāskan,o un jādabū zem vienas cepures dažādi vēlējumi, jāsaskaṇo dažādas gaumes un dažādi, bieži vien pilnīgi pretrunīgi uzskati. Mēdz teikt - pēc drūma negaisa spīd atkal saulīte. Tā arī pieminekḷa celšanas gaitā, sākto ceḷu neatlaidīgi turpinot, tumši mākoṇi izklīda, un pieminekḷa īstenošanas gaita sekmīgi virzījās uz priekšu... Mìlais pieminekli, stāvi nu stalts un cēls par prieku mums visiem, par prieku skatītājiem un arī par prieku darba veicējiem un palīgiem!..» [23].

3. attēls. V. Bergkinds (1. no kreisās) ar R. Plāti Šveicē 70. gadu sākumā. Foto no Madonas Novadpētniecības un mākslas muzeja fondiem.
Madonas pilsētas inženieris

Voldemārs

Bergkinds

(1897-1978)

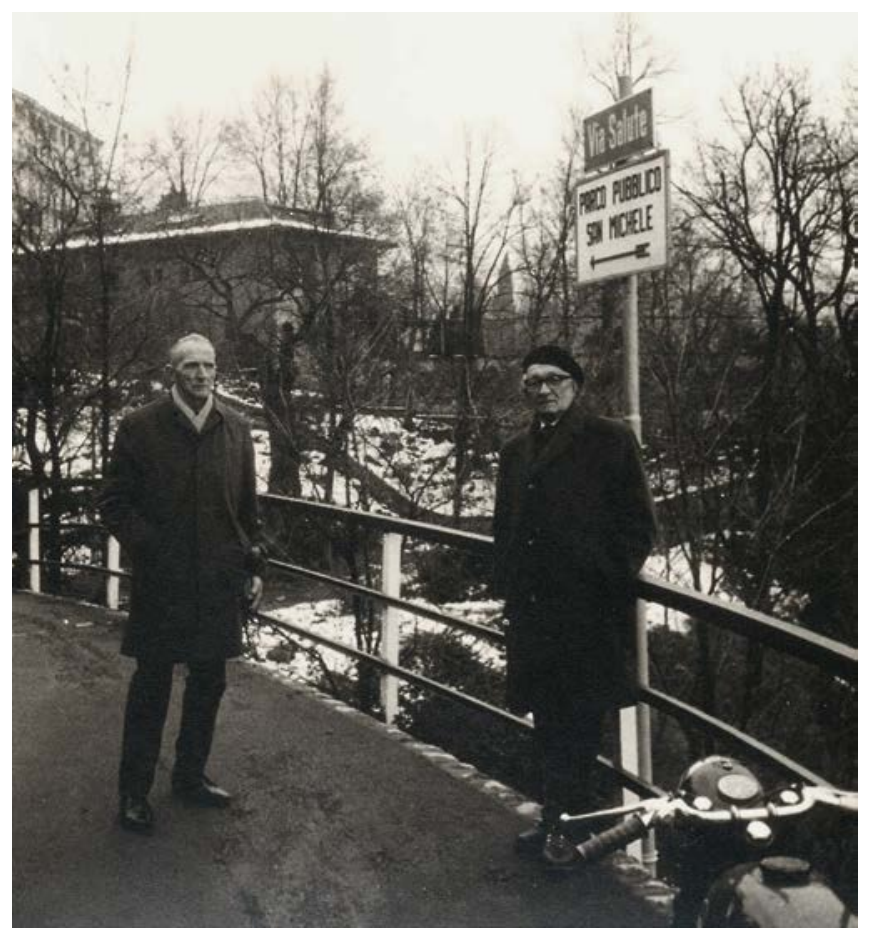


Mūža nogalē V. Bergkinds piedalījās visos latviešu sarīkojumos Insbrukā un ar savu sirsnību bija iemantojis daudz draugu. Austrijā viṇam līdzās bija dzīvesbiedre G̣ertrūde, jo, domājams, Otrā pasaules kara notikumi nošķīra inženieri no iepriekšējās sievas. Kādreizējā rīdzinieka Voldemāra Bergkinda mūžs noslēdzās 1978. gada 10. janvārī [4].

\section{AVOTU UN LITERATŪRAS SARAKSTS}

[1] Latvijas Valsts vēstures arhīvs (turpmāk LVVA), 235. f., 10. apr., 20. l., 121. lp.

[2] LVVA, 7427. f., 1. apr., 4. l., 1. lp.

[3] LVVA, 7427. f., 1. apr., 4. l., 7. lp.

[4] V. V. Austrijā miris dipl. inž. V. Bergkinds. Laiks, 1978, Nr. 11, 6. lpp.

[5] LVVA, 2996. f., 2. apr., 15120. l., 10.-14. lp.

[6] 4. Saraksts. Inženieri. Valdības Vēstnesis, 1923, Nr. 164, 2. Ipp.

[7] Iecelšana. Valdības Vēstnesis, 1923, Nr. 103, 1. lpp.

[8] Iecelšanas. Valdības Vēstnesis, 1927, Nr. 195, 1.lpp.

[9] LVVA, 2095. f., 2. apr., 1. l., 61. lp.

[10] LVVA, 6343. f., 12. apr., 176. l.

[11] Madonas Novadpētniecības un mākslas muzejs (turpmāk MNMM), 37651:21

[12] MNMM, 37664:5

[13] Noslēgusies hipotēku bankas mazēku sacensība. Mūsu İpašums, 1939, Nr. 30, 502. lpp.

[14] LVVA, 6643. f., 1. apr., 162. l.

[15] MNMM, 38140

[16] MNMM, 38141:4

[17] Krastiṇš, J. Latvijas Republikas būvmāksla. Rīga: Zinātne, 1992, 182. lpp.

[18] MNMM, 20702

[19] MNMM, 38145:3

[20] MNMM, 38151:1

[21] Tāls cel̦š ir noiets. Latvija, 1972, Nr. 41, 3. lpp.

[22] Grīnuma, G. Piemingas paradoksi. Rīga: Karogs, 2009, 335. lpp.

[23] Raiṇa un Aspazijas pieminekli atklājot. Treji Vārti, 1974, Nr. 43/44, 8. lpp. 


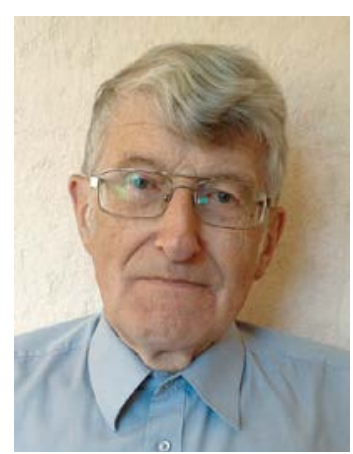

INDULIS ZVIRGZDIN̦Š, Mg. hist., obtained a Master degree from the University of Latvia in 1996. He is currently a Senior Researcher with Madona Museum of Local History and Art. His main academic interests include the history of Madona and Madona district. He is the author of many publications.

Address: Madona Museum of Local History and Art, Skolas iela 12, Madona, LV-4801, Latvia

E-mail: i.zvirgzdins@madona.lv

Indulis Zvirgzdiṇš

\section{Madona City Engineer Voldemārs Bergkinds (1897-1978)}

Civil engineer Voldemārs Bergkinds started his studies at the Department of Civil Engineering of Riga Polytechnic Institute and continued at the University of Latvia. In 1922, he received the Diploma of Civil Engineer and was a road engineer with the Ministry of Transport of Latvia. He has developed the design for various new buildings and modifications of the existing ones. Some of the buildings he designed can be seen in Madona. Bergkinds had been the Civil Engineer of the town of Madona since 1928. After World War II, he lived and worked in Austria. He took part in the construction of the monument to Latvian poets Rainis and Aspazija in Castagnola, Lugano, Switzerland. The monument was restored in 1972. Bergkinds died in January 1978 at the age of 80 in Innsbruck, Austria, where he was buried.

Keywords: Voldemārs Bergkinds, road construction, building design, Madona, monument to Rainis and Aspazija in Switzerland.

Индулис Звиргздыньш

\section{Инженер города Мадона Волдемарс Бергкиндс (1897-1978)}

Инженер-строитель Волдемарс Бергкиндс начал учебу на Инженерном отделении Рижского политехнического института и продолжил в Латвийском университете, где в 1922 году получил диплом. Он работал в качестве инженера-строителя в Министерстве сообщения Латвии, а также разработал целый ряд новых конструкций в процессе реконструкции зданий. С 1928 года В. Бергкиндс работал инженером в городе Мадоне. Несколько зданий, построенных в городе по его проекту, сохранились до наших дней. После Второй мировой войны он жил и работал в Австрии. Он являлся одним из активистов по постройке памятника латышским поэтам Райнису и Аспазии в Кастаньоле, Лугано, Швейцария. Памятник был открыт в 1972 году. Скончался В. Бергкиндс в Инсбруке в январе 1978 года, в возрасте восемидесяти лет.

Ключевые слова: Волдемарс Бергкиндс, дорожное строительство, проектирование зданий, Мадона, память о Райнисе и Аспазии в Швейцарии. 